\title{
Molecular characterization of a putative serine protease from Trichinella spiralis and its elicited immune protection
}

\author{
Ge Ge Sun, Hua Nan Ren, Ruo Dan Liu, Yan Yan Song, Xin Qi, Chen Xi Hu, Fan Yang, Peng Jiang, Xi Zhang, \\ Zhong Quan Wang* and Jing Cui
}

\begin{abstract}
In our previous work, a Trichinella spiralis putative serine protease (TSSP) was identified from ES products of T. spiralis intestinal infective larvae (IIL) and adult worms (AW) by immunoproteomics: it was highly expressed in IIL compared with muscle larvae (ML). In this study, the TsSP biological characteristics in larval invasion and growth were identified and its potential as a vaccine target against Trichinella infection were investigated. Expression of TsSP at various developmental phases (newborn larvae, ML, IIL, and AW) was detected by qPCR, immunofluorescent test and Western blotting. The rTsSP could specifically bind to the intestinal epithelial cell (IEC) membrane and enter into the cytoplasm. Anti-rTsSP serum suppressed the larval invasion of enterocytes in a dose-dependent mode, and killed newborn and ML of T. spiralis, decreased larval infectivity and development in the host by an ADCC-mediated mechanism. Immunization of mice with rTsSP produced a Th2 predominant immune response, and resulted in a $52.70 \%$ reduction of adult worms at 5 days post-infection (dpi) and a $52.10 \%$ reduction of muscle larvae at $42 \mathrm{dpi}$. The results revealed there was an interaction between TsSP and the host's IEC; TSSP might be a pivotal protein for the invading, growing and parasiting of this nematode in the host. Vaccination of mice with rTsSP elicited immune protection, and TsSP is a potential target molecule for vaccines against enteral Trichinella infection.
\end{abstract}

\section{Introduction}

Trichinellosis is an important zoonotic parasitic disease worldwide, especially in developing countries [1]. Trichinella infection results from the ingestion of raw or poorly cooked meat containing the larvae of the genus Trichinella [2]. Trichinella infection in animals and humans is recorded in 66 countries all over the world, and has been regarded as an emerging or re-emerging zoonotic disease [3]. Trichinella spiralis is the major etiological agent of Trichinella infection in humans, and its main reservoir is domestic pigs [4]. In China, 15 outbreaks of human trichinellosis were reported during 2004-2009, pork and pork-related products were the main sources of infection [5-7]. Trichinella infection in domestic pigs is a major public hygiene problem and hazard animal food safety

*Correspondence: wangzq2015@126.com; cuij@zzu.edu.cn Department of Parasitology, Medical College, Zhengzhou University, Zhengzhou 450052, China
[8]. There are increasing cosmopolitan demands for reliable preventive measures for Trichinella infection in food animals to ensure meat safety [9]. Therefore, the exploitation of vaccines to prevent domestic swine from Trichinella infection is a promising measure for the control of this zoonosis [10-13].

The lifecycle of $T$. spiralis is completed in a single host, the adult worms (AW) and larvae reside in the same host's intestine and skeletal muscles, respectively. Once the contaminated meat is ingested, the muscle larvae (ML) of T. spiralis are liberated from the capsules, migrate to the small intestine, and develop into intestinal infective larvae (IIL) upon activation by bile $[14,15]$. The IIL invade the small intestinal epithelium, undergo four molts and finally develop into adults. The AW copulate and adult females begin depositing the newborn larvae (NBL) at 5 days post-infection (dpi). Then, the NBL enter blood circulation, penetrate into skeletal muscles and encapsulate, and the lifecycle is accomplished [16]. 
However, the mechanism of invasion of enteral epithelium by $T$. spiralis IIL is still unknown. The larval surface or excretory-secretory (ES) proteases might participate in larval invasion of enteral epithelium [17-19]. Previous studies revealed that the IIL generates several proteases and invades the cell monolayer while they co-culture with the intestinal epithelial cell (IEC) monolayer [20, 21]. These proteases might interact with IEC and act as a principal part in the process of larval invasion of intestinal mucosa, and they are likely the potential vaccine targets against intestinal Trichinella infection.

In our previous studies, a putative serine protease of $T$. spiralis (TsSP) (GenBank accession no. ABY60762) was identified in ES products from T. spiralis IIL and AW by immunoproteomics with early infection sera from mice and patients with trichinellosis [19, 22]. Moreover, the TsSP gene was highly expressed in the IIL stage compared with the ML stage [18]. The complete TsSP cDNA sequences were cloned and expressed in our department $[22,31]$. Sequence analysis showed that the complete cDNA sequences of TsSP gene were $1236 \mathrm{bp}$. The TsSP open reading frame (ORF) encodes a $45.2 \mathrm{kDa}$ protein of 411 amino acids. The signal peptide is located between 1-18 aa. The TsSP has a domain of trypsin-like serine protease carrying an active site of classic catalytic triad (Serine-Histidine-Aspartat) for proteolysis.

In this study, the biological property and function of TsSP in T. spiralis invasion and development were characterized, and the immune protection generated by immunization with the rTsSP was also evaluated in a mouse model.

\section{Materials and methods}

\section{Parasites and experimental animals}

Trichinella spiralis isolate (ISS534) was acquired from a naturally infected pig in Henan Province of China. This isolate was passaged at an interval of each 6 months in $\mathrm{BALB} / \mathrm{c}$ mice in our department. Female, 6-8 weeks old $\mathrm{BALB} / \mathrm{c}$ mice were obtained from the Experimental Animal Center of Zhengzhou University.

\section{Collection of worms and protein preparation}

The ML was obtained by artificially digesting mouse carcasses experimentally infected with $T$. spiralis at $42 \mathrm{dpi}$ $[23,24]$. The IIL were separated from the intestines of mice infected orally with $5000 \mathrm{ML}$ at 6 hours post-infection (hpi), and AW was isolated from the intestines at 3 and $6 \mathrm{dpi}$, respectively. The NBL were recovered from the pregnant females at $6 \mathrm{dpi}$ and cultured at $37{ }^{\circ} \mathrm{C}$ for $24 \mathrm{~h}$ [25]. These worms were respectively added into $20 \mathrm{mM}$ pH 7.2 Tris- $\mathrm{HCl}$ buffers, supplemented with protease inhibitors and sonicated (99 cycles of $5 \mathrm{~s}$, and lapse times of $5 \mathrm{~s}$ at $0{ }^{\circ} \mathrm{C}$ ). The lysates were centrifuged at
$4{ }^{\circ} \mathrm{C}$ and $10000 \mathrm{~g}$ for $20 \mathrm{~min}$. The soluble crude proteins and excretory/secretory (ES) proteins of ML, IIL and AW were prepared [26]. The concentration of worm protein was assayed as reported previously [27].

\section{Cell culture and protein preparation}

The IEC was prepared from fetal mouse intestines and used for the in vitro larval invasion assay [28]. The $\mathrm{C} 2 \mathrm{C} 12$ cell (mouse striated muscle myoblast) was resistant to invasion and utilized as the negative control [29]. The cells were cultivated in Dulbecco's modified Eagle's medium and collected by trypsinization. The IEC lysate proteins were prepared by grinding, sonicating and centrifuging [30].

\section{Immunization of mice with the rTsSP}

The complete TsSP cDNA sequences were cloned, and the recombinant plasmid $\mathrm{pQE}-80 \mathrm{~L} / \mathrm{TsSP}$ was transformed into Escherichia coli BL21 (DE3) (Novagen, USA). The rTsSP protein expression was induced for $4 \mathrm{~h}$ at $30{ }^{\circ} \mathrm{C}$ with $0.5 \mathrm{mM}$ IPTG in our laboratory [31]. The rTsSP was purified using a Ni-NTA His-tag affinity kit (Novagen). A total of $60 \mathrm{BALB} / \mathrm{c}$ mice were randomly divided into three groups (20 mice per group). The experimental group of mice was immunized with rTsSP. Each mouse was immunized with abdominal subcutaneous injection with $20 \mu \mathrm{g}$ of rTsSP emulsified in Freund's complete adjuvant, subsequently boosted twice at a 10 days interval using the same dose of rTsSP emulsified with Freund's incomplete adjuvant [32]. The control group was vaccinated with only adjuvant or PBS. Ten days post the ultimate boost, all mice were orally inoculated with 300 T. spiralis ML. Blood samples from tail veins of vaccinated mice were collected at $0,10,20,30$ and 40 days after immunization [33]. Pre-immune serum was also collected and utilized as negative serum control.

\section{Real-time quantitative PCR (qPCR)}

Total RNA from diverse T. spiralis phases (NBL, ML, IIL and AW) were prepared using TRIzol reagent (Invitrogen). In order to eliminate the contamination with DNA, all RNA were pre-treated with DNase I (Thermo Fisher Scientific, San Francisco, CA, USA). qPCR was carried out as described [34]. The $20 \mu \mathrm{L}$ of reaction mixture consisted of $1 \times$ iTaq Universal SYBR ${ }^{\circledR}$ Green (Bio-Rad Laboratories, Inc.), $2 \mu \mathrm{L}$ of the first-strand cDNA, and $300 \mathrm{nM}$ each of the Fwd and Rev Primer. The primer for TsSP qPCR was as follows: $5^{\prime}$-CTTTTCAAGTGCTTA TTTCTC-3' ${ }^{\prime}$ and 5'-TATTACCCGCTTTTCTGAAC-3'. The TsSP transcription level was standardized by subtracting the transcription level of Glyceraldehyde 3-phosphate dehydrogenase (G3PDH) of the same group. qPCR amplification was conducted using LightCycler ${ }^{\circledR} 480$ II 
Real-Time PCR System (Roche Applied Science, Mannheim, Germany), according to the following procedures: $95^{\circ} \mathrm{C}$ for $30 \mathrm{~s} ; 40$ cycles of $95^{\circ} \mathrm{C}$ for $15 \mathrm{~s}$ and finally $60^{\circ} \mathrm{C}$ for $1 \mathrm{~min}$. A melting curve analysis was carried out at $65-95{ }^{\circ} \mathrm{C}$. The TsSP transcription levels were calculated on the basis of a $2^{-\Delta \Delta \mathrm{Ct}}$ formula [18]. The experiment was performed using three replicates and each sample had three replicates.

\section{TsSP expression in various stages identified by Western blot analysis}

Soluble and ES proteins from various stages of T. spiralis (NBL, ML, IIL and AW) were identified by Western blot analysis with anti-rTsSP serum. Protein samples were separated by SDS-PAGE in $12 \%$ polyacrylamide gels. After electrophoresis, the gels were transferred to nitrocellulose membranes (Merck Millipore, Billerica, MA, USA) [35]. Membranes were blocked at $37{ }^{\circ} \mathrm{C}$ for $2 \mathrm{~h}$ with $5 \%$ skimmed milk in Tris-buffered saline with Tween-20 (TBST). The membranes were washed three times and incubated with 1:100 dilutions of anti-rTsSP serum. After being washed again, the membranes were further incubated with HRP-conjugated goat anti-mouse IgG (1:10 000). The coloration was developed using 3,3'-diaminobenzidine tetrahydrochloride (DAB; Sigma, USA) and terminated by washing the membrane with deionized water.

\section{Immunostaining of TsSP at various stages by immunofluorescent test (IFT)}

Immunostaining of TsSP at various $T$. spiralis whole worm stages (NBL, ML, IIL, AW and embryos) and 3- $\mu \mathrm{m}$ cryosections of ML and AW was performed as described $[36,37]$. Briefly, the intact worm was immersed in $100 \%$ cold acetone for $20 \mathrm{~min}$. The worms were spread on polylysine-coated slides, permeabilized using $1 \%$ Triton X-100 for $5 \mathrm{~min}$, and blocked with 3\% bovine serum albumin (BSA). Adult females were incised from their middle to release embryos on slides, and the embryos were covered with a cover slip. The slides were first put into liquid nitrogen, and then fixed with $100 \%$ cold acetone for $20 \mathrm{~min}$ after the cover slip was taken out. After washing, the whole worms and sections were blocked at $37{ }^{\circ} \mathrm{C}$ for $2 \mathrm{~h}$ with $3 \% \mathrm{BSA}$, reacted with 1:10 dilutions of anti-rTsSP serum, and stained at $37^{\circ} \mathrm{C}$ for $1 \mathrm{~h}$ with 1:100 dilutions of cy3/FITC-conjugated goat anti-mouseIgG. Subsequently, the whole worms were incubated with a $4^{\prime}, 6$-diamidino-2-phenylindole (DAPI) at $37^{\circ} \mathrm{C}$ for $5 \mathrm{~min}$. Finally, the slides were treated with $70 \%$ glycerol and observed with a fluorescent microscope (Olympus, Japan).

\section{Determination of rTsSP-specific antibodies by ELISA}

Serum anti-rTsSP antibodies (total IgG, IgG1 and IgG2a) of vaccinated mice were assayed by ELISA at 10 days following each vaccination [38, 39]. Briefly, the plates were coated with $2 \mu \mathrm{g} \mathrm{rTsSP} / \mathrm{mL}$ and incubated with mouse sera diluted at 1:100 in PBST. After being washed, the plate was incubated with 1:10 000 dilutions of HRPconjugated goat anti-mouse IgG (or IgG1, IgG2a (SigmaAldrich), then with o-phenylenediamine dihydrochloride (OPD; Sigma-Aldrich). A microplate reader (Tecan, Schweiz, AG, Switzerland) was applied to measure the absorbance at $490 \mathrm{~nm}$.

\section{Assay of binding activity of rTsSP with IEC by far Western}

For far Western analysis of rTsSP and IEC interaction, the protein samples of IEC and $\mathrm{C} 2 \mathrm{C} 12$ were separated with $12 \%$ polyacrylamide gels for $2.5 \mathrm{~h}$ [40]. The gels were transferred to nitrocellulose membranes (Millipore, USA). Then the blots were blocked for $2 \mathrm{~h}$ at $37^{\circ} \mathrm{C}$ by $5 \%$ nonfat milk in TBST. The blots were incubated $\left(37^{\circ} \mathrm{C}\right.$, $2 \mathrm{~h}$ ) with $20 \mu \mathrm{g} / \mathrm{mL}$ rTsSP, and the IIL ES proteins as the control group [30]. Membranes were washed three times and incubated $\left(37^{\circ} \mathrm{C}, 2 \mathrm{~h}\right)$ with 1:100 dilutions of different sera (anti-rTsSP serum, pre-immune serum or infection serum). After being washed completely, the membranes were incubated at $37{ }^{\circ} \mathrm{C}$ for $1 \mathrm{~h}$ with HRP-conjugated anti-mouse IgG, and stained using DAB (Sigma-Aldrich). The IEC protein bands bound with rTsSP were analyzed with the AlphaView Software.

\section{Determination of binding between $r$ TsSP and IEC by ELISA} The binding ability between rTsSP and IEC was also investigated by ELISA [11, 41]. Briefly, the plate was coated with different concentrations of IEC proteins. After being blocked and washed, the following reagents were successively added: different dilutions of the rTsSP, 1:100 dilutions of mouse sera, and HRP-conjugated goat anti-mouse IgG, (1:10 000; Sigma-Aldrich). The plate was respectively incubated at $37^{\circ} \mathrm{C}$ for $2 \mathrm{~h}$. After being reacted with OPD, the absorbance at $490 \mathrm{~nm}$ was measured as before. All samples were run in duplicate.

\section{Binding and cellular localization of rTsSP with IEC by IFT}

The IEC and $\mathrm{C} 2 \mathrm{C} 12$ cell was grown to confluence on glass coverslips in DMEM medium. The monolayer was incubated with $20 \mu \mathrm{g} / \mathrm{mL}$ rTsSP at $37^{\circ} \mathrm{C} 2 \mathrm{~h}$. The IIL ES protein and PBS were respectively utilized as a positive or negative control [30]. After being washed, the monolayer was fixed with $4 \%$ formaldehyde for $20 \mathrm{~min}$. The monolayer was incubated with 1:10 dilutions of anti-rTsSP serum, infection serum or pre-immune serum, then incubated with FITC-conjugated goat anti-mouse IgG diluted 
at 1:100 (Santa Cruz, USA) for $45 \mathrm{~min}$ at $37{ }^{\circ} \mathrm{C}$. Finally, the monolayer was incubated for $5 \mathrm{~min}$ with propidium iodide (PI) to specifically stain the cell nucleus. Upon completion of the staining procedure, the coverslips were transferred to glass slides and observed with fluorescent microscopy (Olympus, Tokyo, Japan) [33]. Moreover, cellular localization of rTsSP within enterocytes was further examined with confocal microscopy and analyzed with Olympus Fluoview software [30].

\section{The in vitro invasion assay}

The IIL was applied for the in vitro invasion assay [15]. The IEC monolayers were overlaid with 200 IIL suspended in semisolid medium with different dilutions of anti-rTsSP serum, infection serum or pre-immune serum, and incubated in $5 \% \mathrm{CO}_{2}$ for $2 \mathrm{~h}$ at $37{ }^{\circ} \mathrm{C}[29$, 42]. The number of larvae invaded within IEC monolayers was counted with an inverted phase-contrast microscope (Olympus, Japan). The IIL penetrated into and migrated in the monolayer were calculated as invaded IIL; when the IIL were still suspended in medium, they were assessed as non-invading IIL [26]. Each invasion assay had three replicates.

\section{In vitro antibody-dependent cellular cytotoxicity (ADCC) assay}

Anti-rTsSP antibody cytotoxicity on T. spiralis NBL and ML was tested as described [43, 44]. Pre-immune and infection serum were respectively utilized as negative or positive controls. Peritoneal macrophages (PM) were obtained from normal mice. One hundred of NBL (or $50 \mathrm{ML}$ ) were added into RPMI 1640 media containing $2 \times 10^{5} \mathrm{PM}$ and 1:5-1:1000 dilutions of anti-rTsSP serum. Then, the plate was incubated in $5 \% \mathrm{CO}_{2}$ at $37{ }^{\circ} \mathrm{C}$ for $72 \mathrm{~h}$. Each measurement was done in triplicate. Worm viability after the ADCC assay was assessed according to their morphology and activity under a microscope. The live NBL and ML were mobile and exhibited wriggling motion; whereas the dead NBL were straight, inactive or disintegrated, the dead ML were immobile and straight as "C" shapes [42]. Additionally, to identify the viability and infectivity of the ML in ADCC assay, each mouse from three groups of mice was inoculated orally with $100 \mathrm{ML}$ treated by ADCC assay for $24 \mathrm{~h}$ with 1:100 dilutions of different serum. The cytotoxicity of anti-rTsSP antibodies on the ML was further evaluated on the basis of recovered intestinal AW at $3 \mathrm{dpi}$ and larvae per gram (LPG) muscle collected from inoculated mice at $42 \mathrm{dpi}[13,35]$.

\section{Challenge infection and protective efficacy evaluation}

To evaluate the immune protection, three groups of mice were challenged orally with $300 \mathrm{ML}$ of $T$. spiralis 10 days after the last immunization. Adults in the intestine were recovered from 10 mice at $5 \mathrm{dpi}$, and the ML in skeletal muscles was collected from another ten mice at $42 \mathrm{dpi}$. The worm reduction rates in AW and ML were evaluated in accordance with the number of collected intestinal AW and larvae per gram (LPG) muscles from the immunized mice with $\mathrm{rTsSP}$ relative to those from PBS control $[11,45]$.

\section{Statistical analysis}

The statistical analysis of data was performed using SPSS 17.0 software. All data are shown as arithmetic mean \pm standard deviation. One-way ANOVA or Student's t-test was applied for comparison among different groups. The level of statistical significance was $P<0.05$.

\section{Results}

qPCR analysis of TsSP gene transcription at different stages The TsSP gene transcription in various stages of T. spiralis was determined by qPCR. In the life cycle of $T$. spiralis, the TsSP gene was transcribed at all developmental stages (NBL, ML, IIL, and AW) (Figure 1). The transcription level of the TsSP gene was not statistically different among different stages $(F=3.620, P=0.05)$.

\section{Western blot analysis of TsSP expression in various stages} The native TsSP protein with $25-47 \mathrm{kDa}$ in ES proteins from T. spiralis IIL, AW at $3 \mathrm{dpi}$ and ML was identified by anti-rTsSP serum using Western blotting (Figure 2A). Furthermore, the native TsSP protein in crude proteins from diverse $T$. spiralis phases (ML, IIL, AW and NBL) was also recognized by anti-TsSP serum (Figure 2B), indicating that the TsSP was expressed in all T. spiralis phases, and was an excretory or secretory protein.

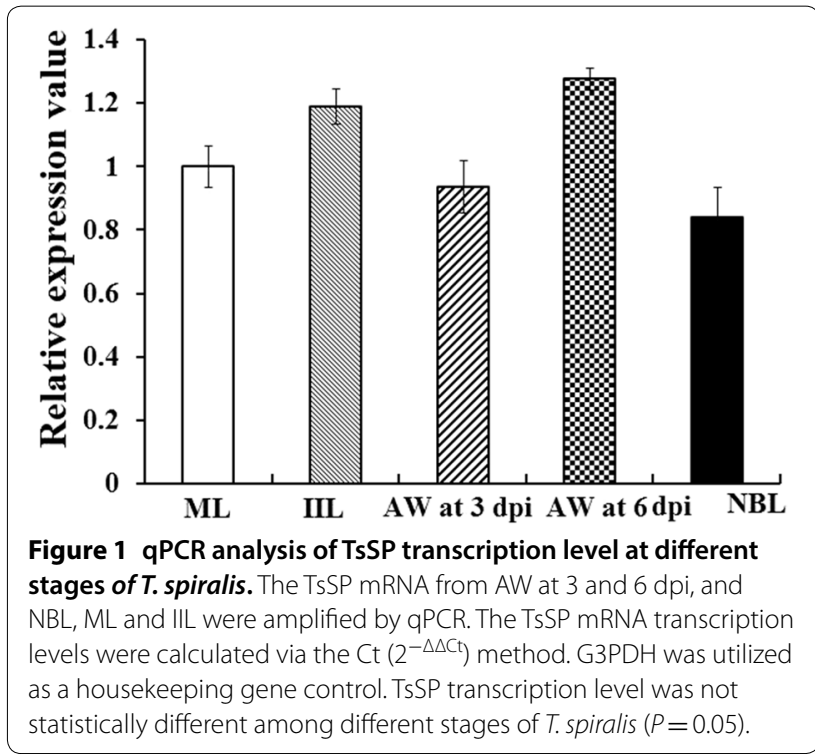




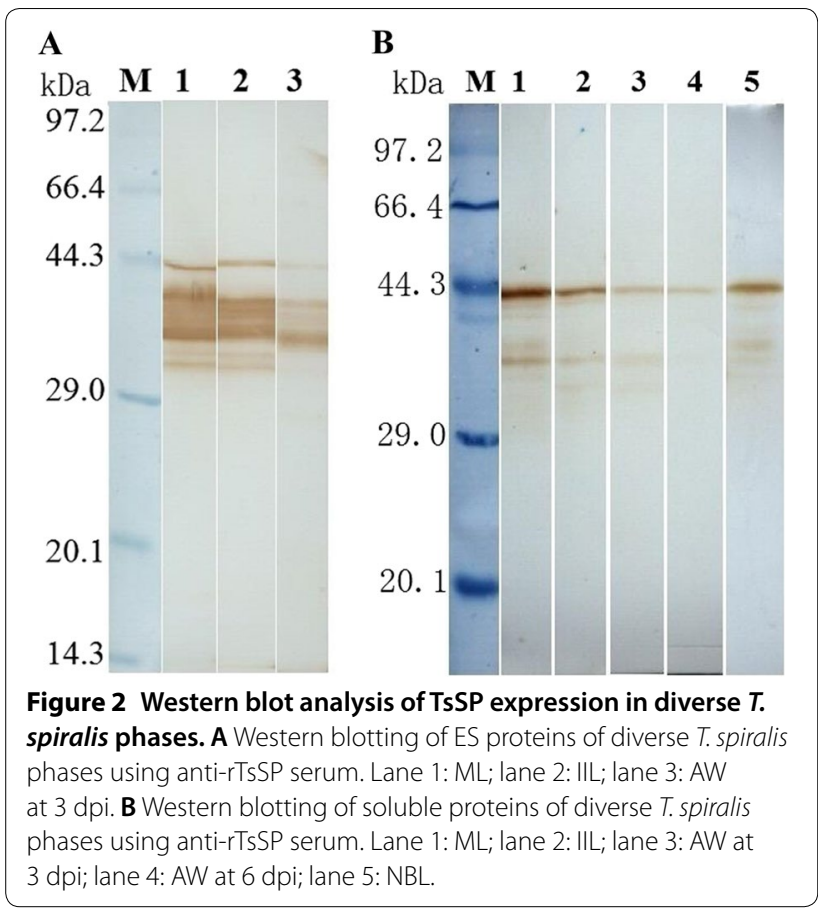

\section{Immunolocalization of TsSP at various stages by IFT}

Expression and immunolocalization of TsSP at different $T$. spiralis stages were investigated by IFT using anti-rTsSP serum, and immunostaining was found in cuticles and whole worm bodies of AW, all embryos (early, medium and late stages), NBL, ML and IIL. The staining of ML and IIL was brighter than those of AW and NBL (Figure 3). When the cryosections of the nematode were incubated with anti-rTsSP serum, the immunostaining was found at the cuticle, stichosome of ML, and embryos of 6 days old female worms (Figure 4). There was no immunostaining in the worms incubated by pre-immune serum or PBS.

\section{Binding of rTsSP to IEC analyzed by far Western analysis}

The results of SDS-PAGE analysis showed that the IEC proteins had about 40 protein bands with a molecular weight of 14.4-97.2 kDa. Far Western results revealed that anti-rTsSP serum identified about 24 bands (14.4$86.5 \mathrm{kDa}$ ) of IEC lysates incubated with rTsSP, and infection serum recognized about 19 bands $(14.4-58.7 \mathrm{kDa})$ (Figure 5A). The binding of IEC proteins with IIL ES protein was also identified by mouse infection sera, but not probed with anti-rTsSP serum, suggesting that the quantity of the native TsSP in IIL ES protein was too low to be detected by far Western. Pre-immune serum did not recognize the IEC proteins incubated with rTsSP (Figure $5 \mathrm{~B}$ ). No binding between $\mathrm{C} 2 \mathrm{C} 12$ proteins and rTsSP was detected (Figure $5 \mathrm{C}$ ). It demonstrated that the rTsSP had a specific binding and interaction with IEC.
Determination of binding between IEC and rTsSP by ELISA The binding affinity between rTsSP and IEC lysates was also assayed by ELISA. There was a strong in vitro interaction between rTsSP and IEC. The binding was IEC protein dose-dependent $(r=0.943, P<0.01)$ and showed an increasing trend with an increase of IEC protein concentration $(F=1044.398, P<0.01)$ (Figure 6A). Moreover, the binding was also rTsSP dose-dependent $(r=0.925$, $P<0.01)$ and showed an increasing trend with an increase of rTsSP concentration $(F=360.641, P<0.01)$ (Figure 6B).

\section{Binding and cellular localization of rTsSP with IEC by IFT}

IFT results revealed that the immunostaining with antirTsSP serum or infection serum was observed on surfaces of IEC incubated with rTsSP. The positive staining using anti-rTsSP serum or infection serum was also seen on IEC incubated with IIL ES proteins. But, no staining of IEC incubated with rTsSP or IIL ES was detected using pre-immune serum. Furthermore, both anti-rTsSP serum and infection serum did not recognize the IEC incubated with PBS or $\mathrm{C} 2 \mathrm{C} 12$ incubated with rTsSP (Figure 7). By confocal microscopy, immunostaining is mainly located in the IEC membrane and cytoplasm (Figure 8), demonstrating that rTsSP can bind to the IEC membrane and enter the cytoplasm.

\section{Inhibition of larval invasion of IEC by anti-rTsSP sera}

When the IIL were added to an IEC monolayer, the larvae invaded the monolayer and migrated within it. When the culture medium was supplemented with 1:50 dilutions of anti-rTsSP serum, infection serum and preimmune serum, the percentages of larvae invading the monolayer were $31.48,15.84$ and $84.16 \%$, respectively $\left(x^{2}=227.786, \quad P<0.01\right)$. The inhibition of anti-rTsSP serum on the IIL invasion of the IEC monolayer was significantly higher than that of the pre-immune serum $\left(\chi^{2}=119.551, P<0.01\right)$. The inhibition was dose-dependent and exhibited a decreasing trend along with a serum dilution increase $(F=198.787, P<0.01)$. However, preimmune serum had no obvious inhibition on larval invasion (Figure 9).

\section{In vitro ADCC assay}

ADCC results showed that anti-rTsSP serum promoted the adherence of PM to NBL and ML (Figures 10,11). When 1:100 dilutions of anti-rTsSP serum was supplemented and incubated for $72 \mathrm{~h}$ at $37{ }^{\circ} \mathrm{C}$, the ADCC caused a significant death of NBL and ML (52 and $44.67 \%$ cytotoxicity, respectively), in comparison with the larvae treated by pre-immune serum (21.33\%, $\left.\chi_{\mathrm{NBL}}^{2}=271.493 ; 18 \%, \chi_{\mathrm{ML}}^{2}=57.520, P<0.01\right)$. The cytotoxicity was the dose-dependent of anti-rTsSP antibody $\left(r_{\mathrm{NBL}}=-0.980, \quad r_{\mathrm{ML}}=-0.961, \quad P<0.01\right)$, which 


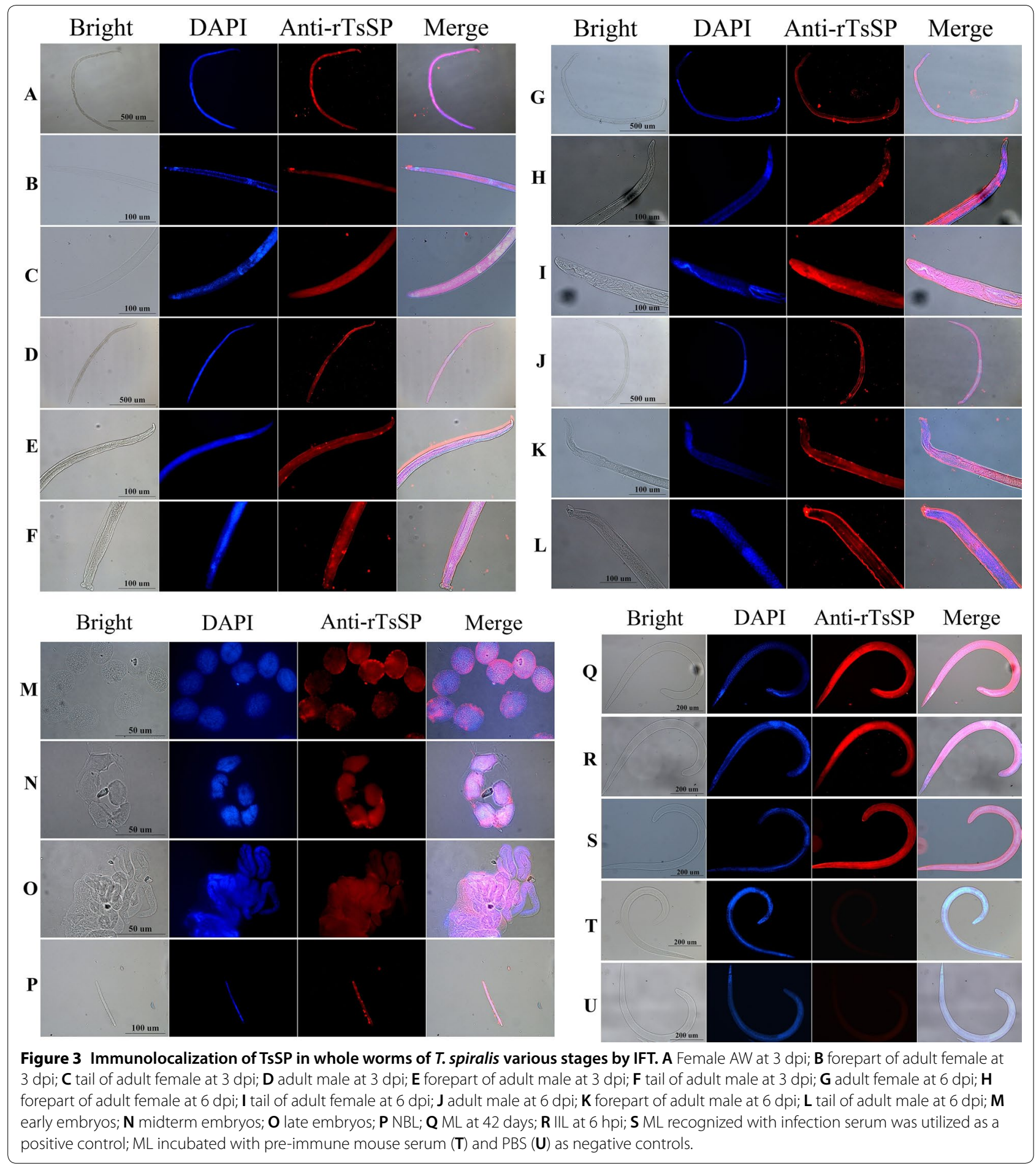

had a decreasing trend following serum dilution elevation $\left(F_{\mathrm{NBL}}=171.618, F_{\mathrm{ML}}=60.175, P<0.05\right)$. There was a significant positive correlation between cytotoxicity and culture time $\left(r_{\mathrm{NBL}}=0.989, r_{\mathrm{ML}}=0.983, P<0.01\right)$; cytotoxicity shows an increasing trend with the prolongation of culture time (Figure 12) $\left(F_{\mathrm{NBL}}=148.587\right.$,
$\left.P<0.01 ; F_{\mathrm{ML}}=144.543, P<0.01\right)$. The mice inoculated orally with ML treated by ADCC assay with anti-rTsSP serum exhibited a $89.40 \%$ reduction of intestinal AW at $3 \mathrm{dpi}$ and a $36.50 \%$ reduction of ML at $42 \mathrm{dpi}$ (Figure 13), when compared with ML treated by pre-immune serum $\left(F_{\text {adults }}=146.561, P<0.01 ; F_{\text {larvae }}=6.255, P<0.01\right)$. These 

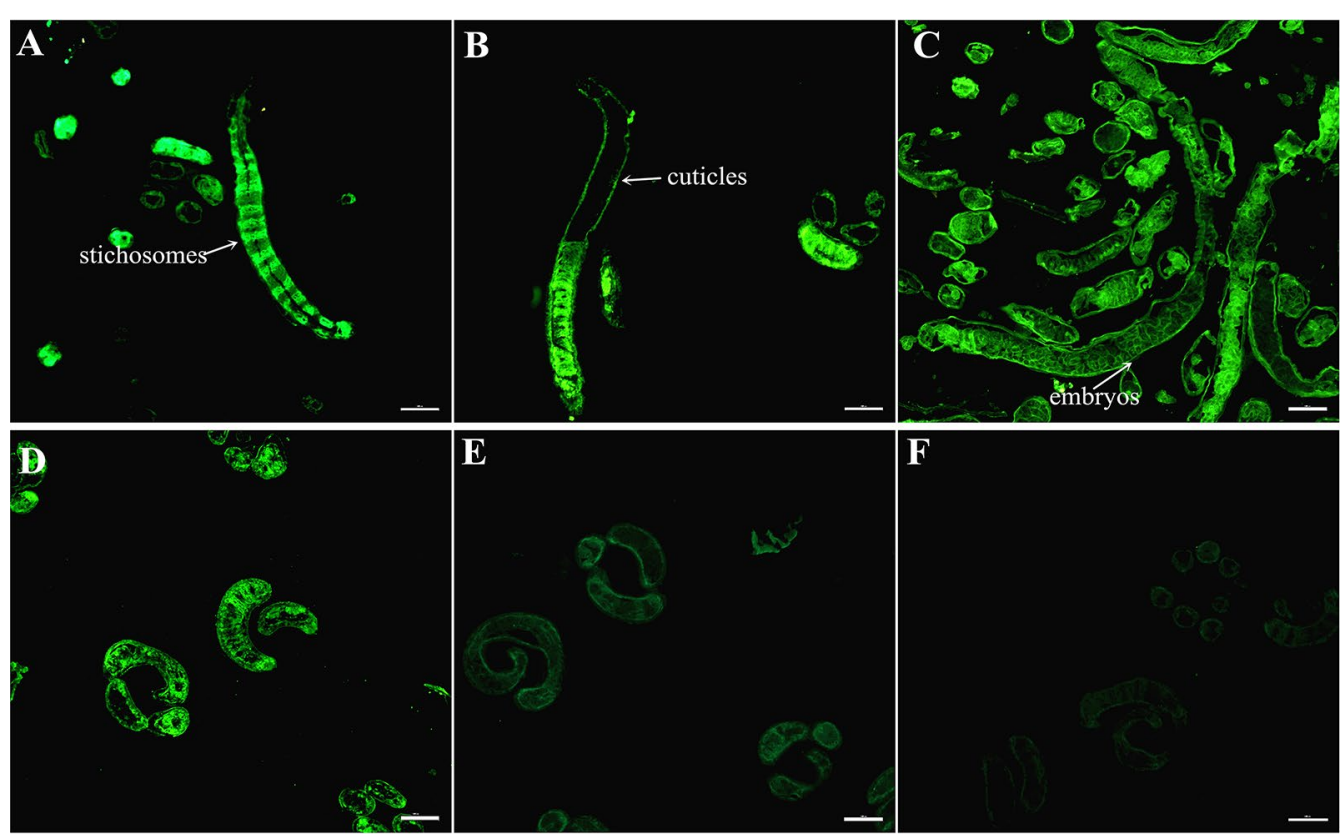

Figure 4 Immunolocalization of TsSP by IFT with cryosections of $T$. spiralis ML and AW. A, B Cryosections of the ML were probed with anti-rTsSP serum, and immunostaining was observed at the cuticle and stichosome of ML. C Cryosections of the 6 days old female adults were recognized by anti-rTsSP serum and the immunostaining was located in embryos of the females. D The ML recognized by mouse infection serum as a positive control. The ML not recognized by pre-immune serum (E) and PBS (F) as negative controls. Scale-bars: $100 \mu \mathrm{m}$.

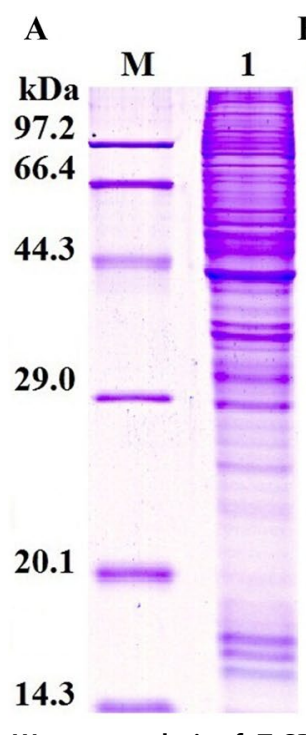

B

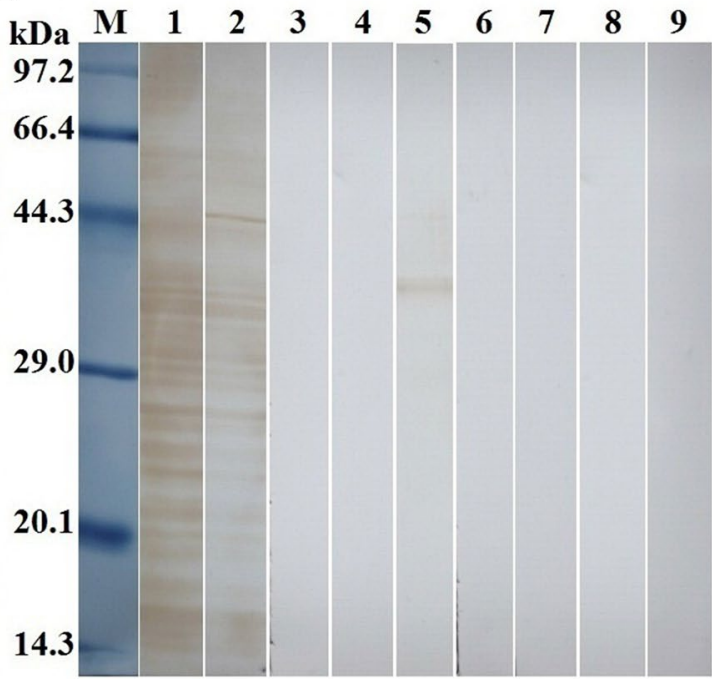

C

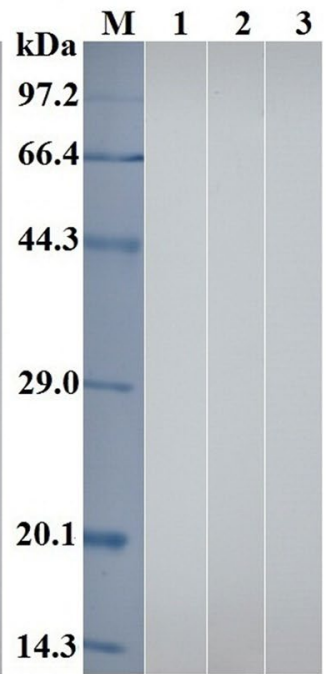

Figure 5 Far Western analysis of rTsSP binding to IEC protein. A SDS-PAGE of the IEC proteins. Lane M: the protein molecular weight marker; lane 1: the IEC lysate proteins. B Far-Western analysis of IEC proteins binding to rTsSP. The IEC protein was first reacted with rTsSP (lanes 1-3), IIL ES proteins (lanes 4-6) or PBS (lanes 7-9), and then recognized using anti-rTsSP serum (lanes 1, 4 and 7), infection serum (lanes 2, 5 and 8) or pre-immune serum (lanes 3,6 and 9). C Far Western analysis of C2C12 protein binding to rTsSP. The C2C12 protein (lanes 1-3) was reacted first with rTsSP, and subsequently incubated with anti-rTsSP serum (lane 1), infection serum (lane 2) or pre-immune serum (lane 3). There was no binding between rTsSP and C2C12 protein.

results suggest that specific anti-rTsSP antibodies could obviously kill the ML and decrease its infectivity by an ADCC fashion.

\section{Immune responses triggered by rTsSP}

In order to evaluate the humoral immune responses to rTsSP, ELISA was utilized to assay anti-rTsSP antibodies 

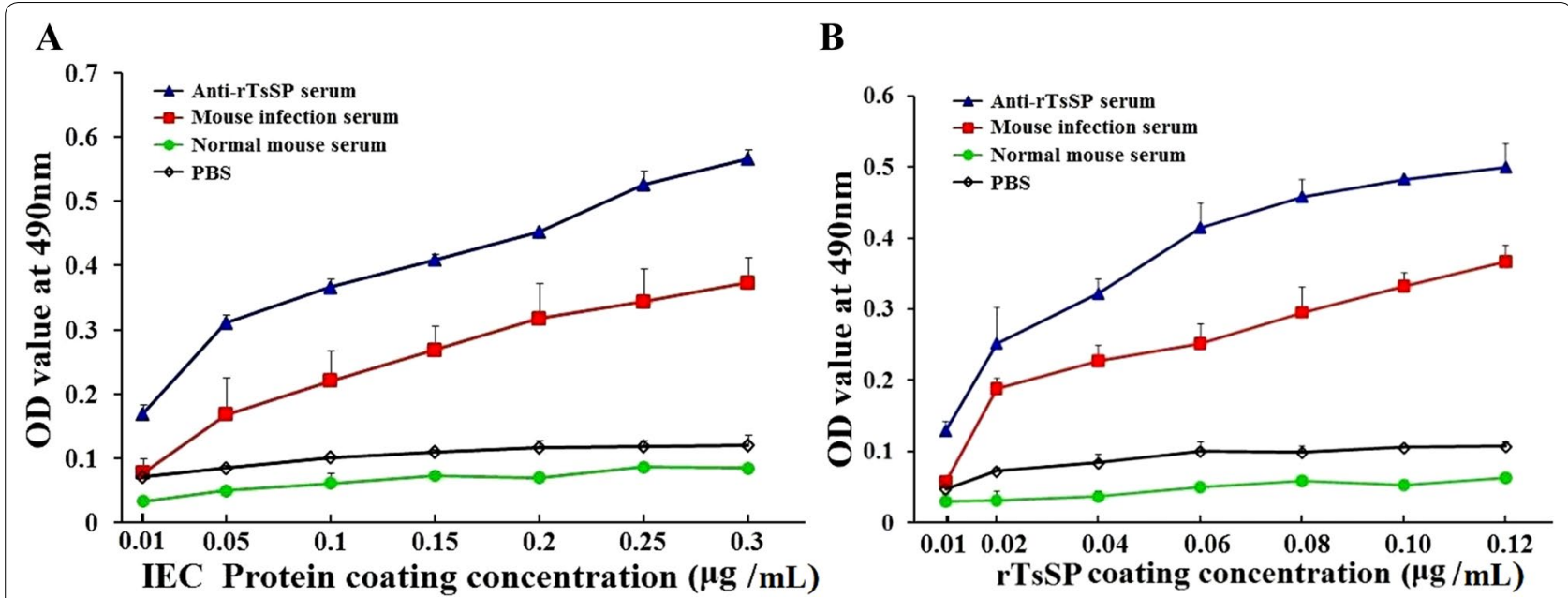

Figure 6 Binding affinity between rTsSP and IEC assayed by ELISA. A The binding between $5 \mu \mathrm{g} / \mathrm{mL} r \mathrm{r} s \mathrm{SP}$ and different concentrations of IEC proteins; $\boldsymbol{B}$ the binding between $2 \mu \mathrm{g} / \mathrm{mL}$ IEC proteins and different concentrations of rTsSP. The binding between rTsSP and IEC proteins is dose-dependent of IEC and rTsSP protein.

(IgG, IgG1, and IgG2a) at different intervals after immunization. The results show that anti-rTsSP IgG level of mice vaccinated with rTsSP was distinctly elevated after the second and third vaccination, but anti-rTsSP IgG was not detected in mice injected with adjuvant or PBS (Figure 14). The level of IgG1 on days 10, 20, 30 and 40 after vaccination was obviously higher than those of IgG2a $\quad\left(t_{10 \text { days }}=13.277, t_{20 \text { days }}=9.146, t_{30 \text { days }}=20.058\right.$, $\left.t_{40 \text { days }}=19.734, P<0.05\right)$, demonstrating that the dominating IgG subclass triggered by rTsSP was IgG1, and Th2-predominant immune response was elicited, but the IgG2a antibody response was also induced after the second immunization with rTsSP.

\section{Immune protective effects of rTsSP}

The mice immunized with rTsSP produced a $52.70 \%$ reduction of intestinal adult worm burden at $5 \mathrm{dpi}$ and a $52.10 \%$ reduction of muscle larval burden at $42 \mathrm{dpi}$ (Figure 15), in comparison with the PBS control group $\left(F_{\text {adult }}=55.914, F_{\text {larva }}=12.612, P<0.01\right)$. Moreover, the adult and larval burden of immunized mice was also significantly lower than those of the adjuvant-injected group alone $(P<0.01)$.

\section{Discussion}

Serine protease is a superfamily of proteolytic enzymes and has a wide variety of biological functions in parasite infection [46]. They are involved in larval invasion, molting, digestion and proteolysis [47, 48]. A previous study showed that a serine protease with "trypsin-like" activities, which was from Schistosoma mansoni cercariae secretory products, was related with the host's skin invasion [49]. A neutral elastase from Onchocerca volvulus ES products degraded host's dermal components (extracellular matrix, laminin, collagen type IV and fibronectin), suggesting that the elastase was related to the degradation of the host's elastic fibres [50]. An elastolytic enzyme was found in ES products of Ancylostoma caninum third-stage larvae. This elastolytic enzyme could prevent fibrin clot formation and promote fibrin clot dissolution [51]. Serine proteases secreted from nematode Trichuris muris degraded the intestinal main mucin (Muc2), depolymerized the mucin network and destroyed the mucus barrier [52].

Some serine proteases (e.g., TspSP-1 and trypsin-like $45 \mathrm{kDa}$ antigen) have been identified in $T$. spiralis $\mathrm{ML}$ and AW ES products [53, 54], and the enzymic activity of serine protease was detected in T. spiralis ML and AW ES products $[55,56]$. When the IIL were co-cultured with IEC, the serine protease expression level in IIL was obviously elevated relative to ML [57]. The monoclonal antibodies against serine proteases TspSP-1 inhibited the larval invasion of IEC and migration, suggesting that TspSP-1 might exert a pivotal function for degrading intercellular or cytoplasmic proteins, consequently facilitating the larval invasion [53]. Anti-TspSP-1.2 serum partially prevented the larval invasion of IEC, and the rTspSP-1.2 protein elicited an immune protection in immunized mice [21]. Another T. spiralis serine protease (Ts-Adsp) was screened from an adult $T$. spiralis cDNA library, and the mice immunized with rTs-Adsp produced a $46.5 \%$ larval burden reduction relative to the control group [58]. Mice immunized with the DNA vaccine from serine protease of $T$. spiralis NBL showed a $77.93 \%$ larval 


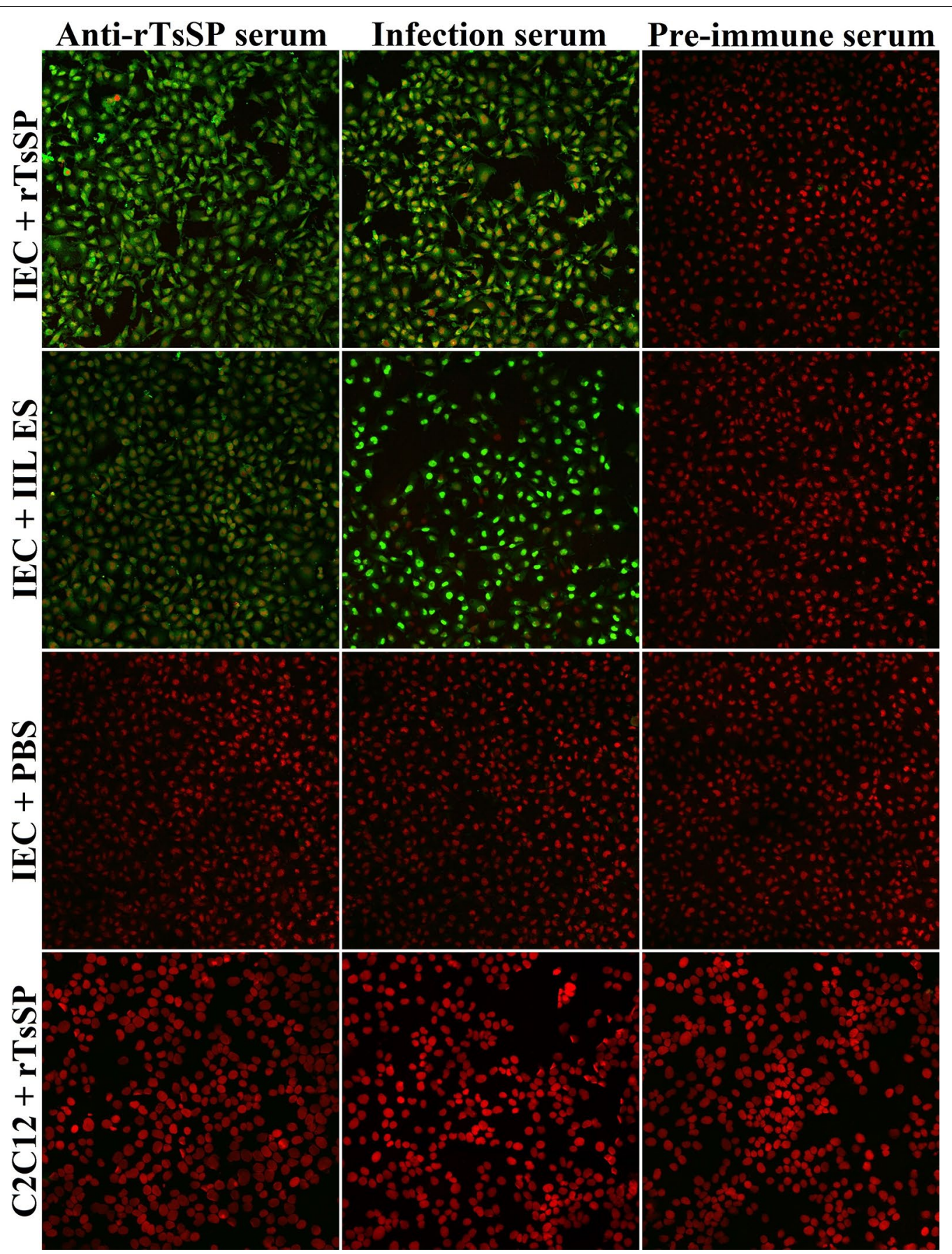

Figure 7 Binding and cellular localization of rTsSP with IEC by IFT $(\times \mathbf{2 0 0})$. The IEC was incubated with rTSSP, IIL ES proteins or PBS at $37^{\circ} \mathrm{C}$ for $2 \mathrm{~h}$. The $\mathrm{C} 2 \mathrm{C} 12$ cell was also incubated with $r T s S P$ at $37^{\circ} \mathrm{C}$ for $2 \mathrm{~h}$. Following washing, the IEC and C2C12 was incubated with anti-rTsSP serum, infection serum or pre-immune serum, and then colored with FITC-labeled goat anti-mouse IgG. Cell nuclei were stained with propidium iodide (PI) as red color. 


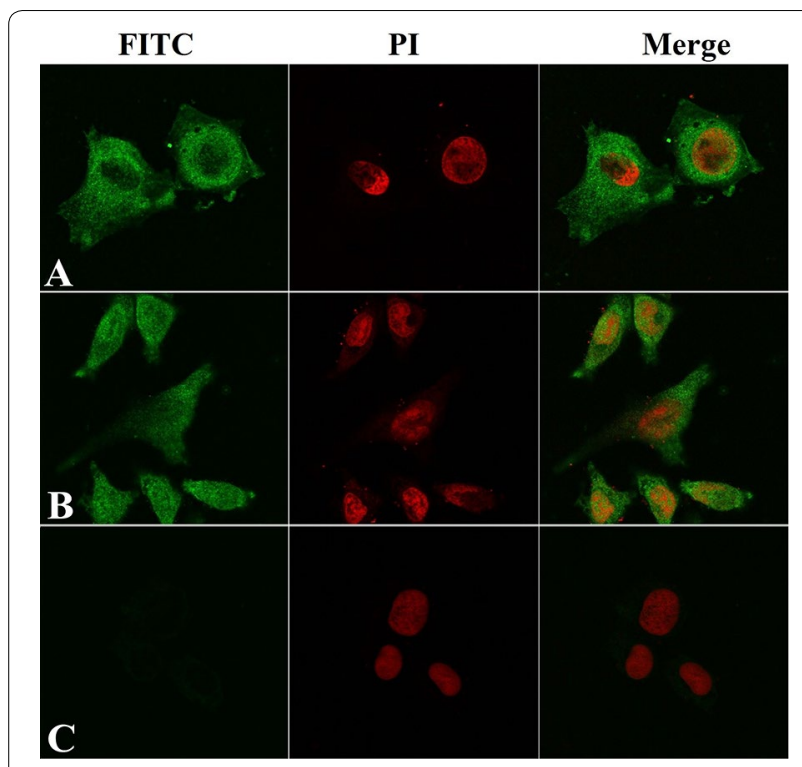

Figure 8 Subcellular localization of rTsSP bonding to IEC by confocal microscopy $(\times 1000)$. The IEC was first incubated with rTsSP, secondly with anti-rTsSP serum (A), infection serum (B) or pre-immune serum $(\mathbf{C})$, and finally with FITC-labeled goat anti-mouse IgG. Cell nuclei were stained using propidium iodide (PI) as red.

reduction after challenge with the ML [13]. These results suggest that serine proteases might be connected with intestinal mucosa invasion and could be potential vaccine targets against Trichinella infection.

In this study, the TsSP transcription was detected by qPCR at different phases of T. spiralis (NBL, ML, IIL and
AW) and the transcription level was not statistically different among different stages. The TsSP expression was observed by IFT at various stages of this nematode, and located in cuticles and whole worm bodies of NBL, ML, IIL, AW and embryos. Other serine proteases of T. spiralis were also expressed in various stages of T. spiralis [26, 59]. The results of Western blot analysis demonstrated that several native TsSP proteins in T. spiralis ES and soluble proteins could be recognized by anti-rTsSP serum, suggesting that the TsSP might have different isoforms, or the TsSP was one member of the serine protease family which has the same functional domains, or the TsSP could possibly be processed by alternative splicing or post-translational modifications $[42,60]$. The results suggest that the serine proteases had housekeeping functions and might be an obligatory protein for T. spiralis larval growth and development.

Far Western blotting has been widely employed in numerous studies on protein-protein interactions [61]. The interaction between rTsSP and IEC was also identified in the present study. Far Western results indicate that anti-rTsSP serum identified about 24 bands of IEC proteins incubated with rTsSP, indicating the rTsSP bound to IEC. The results of IFT and confocal microscopy show that rTsSP can specifically bind to the IEC membrane and enter the cytoplasm. The binding between rTsSP and IEC was the protein dose-dependent as shown in Figure 6 . The results suggest that rTsSP could bind with several IEC proteins [62]. Furthermore, anti-rTsSP antibodies could inhibit the larval invasion of enterocytes and the inhibition was antibody dose-dependent. When
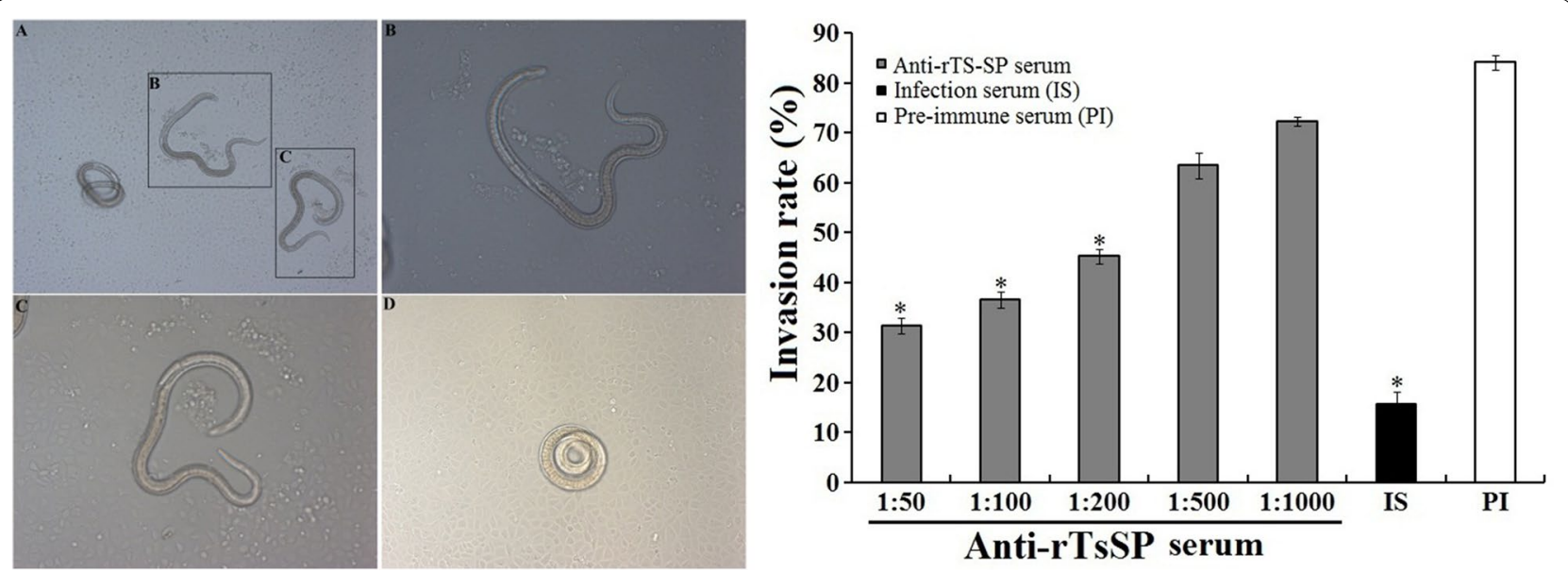

Figure 9 The in vitro inhibition of $T$. spiralis invasion of IEC by anti-rTsSP serum. Left: upon IIL addition to an IEC monolayer, the invaded and non-invaded larvae in monolayer $(\mathbf{A}, \times 100)$. B, C Invaded larva in monolayer $(\times 200)$. D $(\times 200)$ Non-invaded and suspended larva in culture media ( $\times 200)$. Right: inhibition of larval invasion of IEC through various dilutions of anti-rTsSP serum. Infection serum (IS, 1:50 dilution) and pre-immune serum $(\mathrm{PI}, 1: 50)$ were respectively utilized as a positive and negative control. The results are expressed as the percentages of the larvae invading the monolayer and they are shown as the mean \pm SD of three independent experiments. Asterisks indicate remarkable differences $(P<0.01)$ relative to pre-immune serum. 

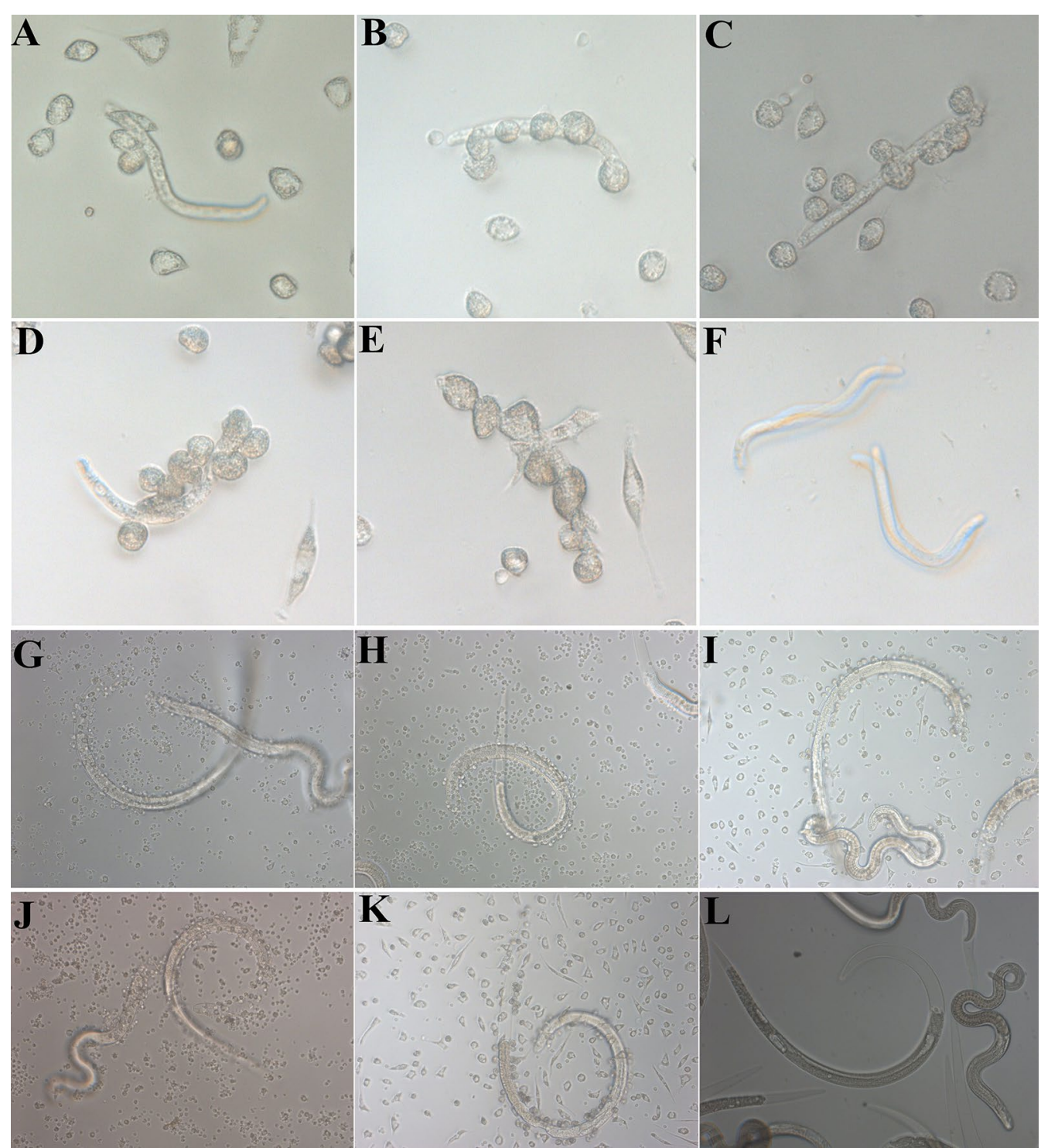

Figure 10 T. spiralis NBL and ML at different times after ADCC assay. In the assay, the NBL (A-F) and ML (G-L) were cultured with anti-rTsSP serum and $2 \times 10^{5}$ mouse peritoneal macrophages (PM) at $37^{\circ} \mathrm{C}$ for different times, $\mathbf{A}, \mathbf{G} 6$ h; B, H 12 h; C, I 24 h; D, J: 48 h; E, K: 72 h; F (NBL) and I (ML): incubation without MPM for $72 \mathrm{~h}$ as a non-MPM control.

the 1:50 dilutions of different serum were used, the inhibition of infection serum on the larval invasion was more evident than those of anti-rTsSP serum. It is likely that the antibodies against other T. spiralis proteins (e.g., glutathione S-transferase, nudix hydrolase) in infection sera also took part in inhibition of larval invasion [30, 42, 48, 63]. The results indicate that there was a protein-protein interaction between TsSP and IEC, and TsSP might play an important part in larval invasion of the host's intestinal epithelium. Nevertheless, the interaction mechanism of TsSP and IEC should be studied in future experiments.
Anti-Trichinella antibodies killed T. spiralis larvae through an ADCC mode [42, 43]. Our results from the ADCC test indicate that anti-rTsSP antibodies participated in the killing of T. spiralis NBL and ML. Peritoneal macrophages adhered to and damaged the larvae with the aid of anti-rTsSP serum, and the killing was also antibody dose-dependent. When the mice were inoculated orally with ML treated by ADCC, the reduction of intestinal adult worms reached up to $89.40 \%$. The results indicate that anti-rTsSP antibodies significantly killed the ML, decreased larval infectivity, and 


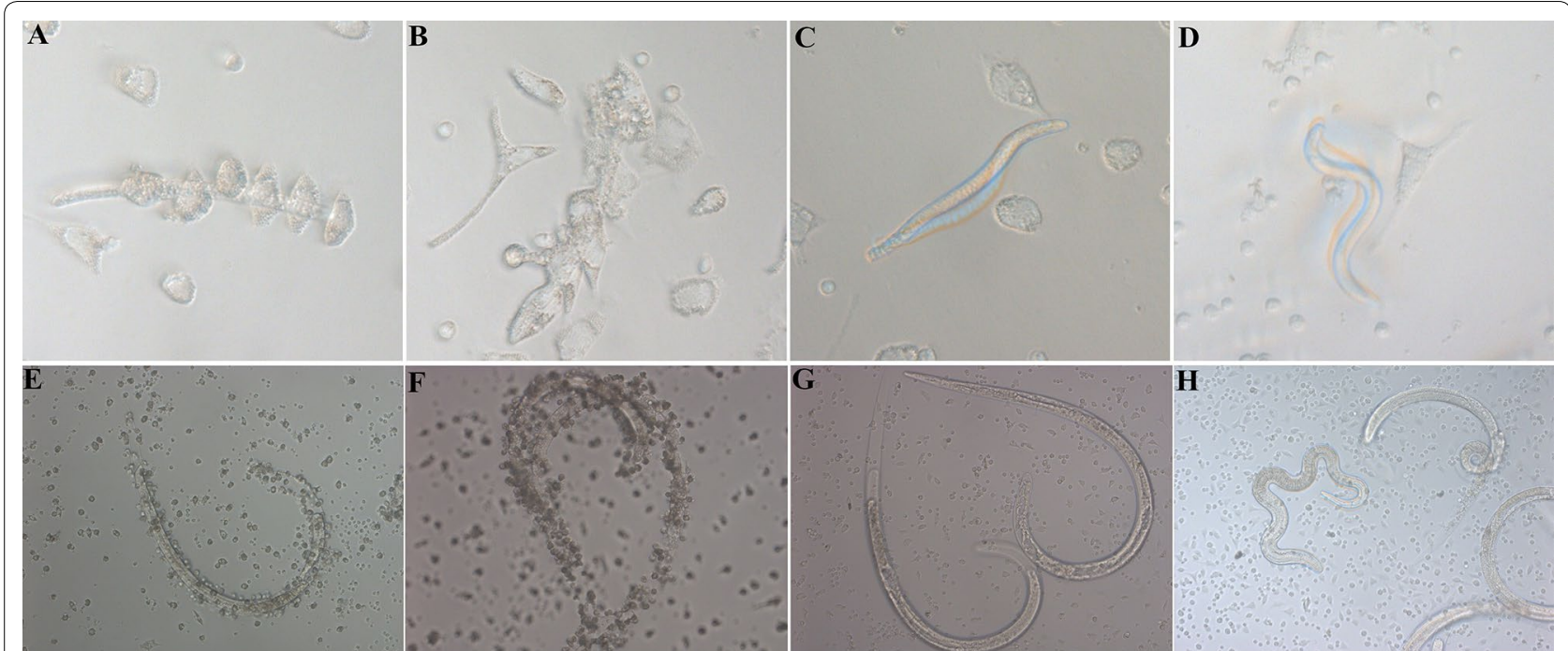

Figure 11 T. spiralis NBL and $\mathbf{M L}$ at $\mathbf{7 2} \mathbf{h}$ after $\mathbf{A D C C}$ with different serum. In the assay, the NBL $(\mathbf{A}-\mathbf{D})$ and $M L(\mathbf{E}-\mathbf{H})$ were cultured at $37^{\circ} \mathrm{C}$ for $72 \mathrm{~h}$ with $2 \times 10^{5}$ mouse peritoneal macrophages (PM) and different mouse serum, $\mathbf{A}, \mathbf{E}$ anti-rTsSP serum; $\mathbf{B}, \mathbf{F}$ infection serum; $\mathbf{C}, \mathbf{G}$ pre-immune serum; D, H PBS. No PM adhered to the live larvae cultured with pre-immune serum and PBS.

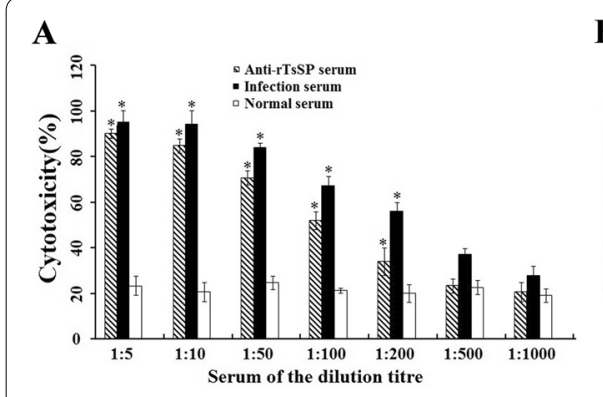

B

D

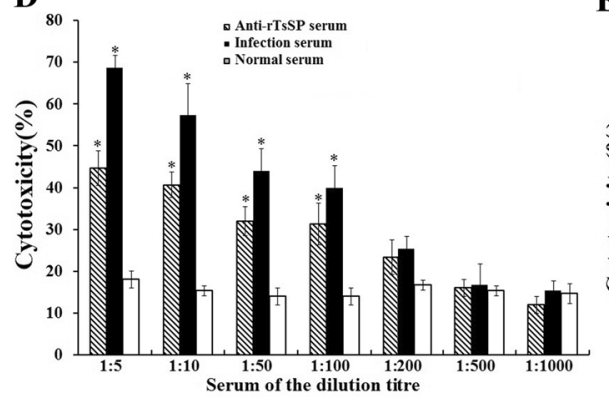

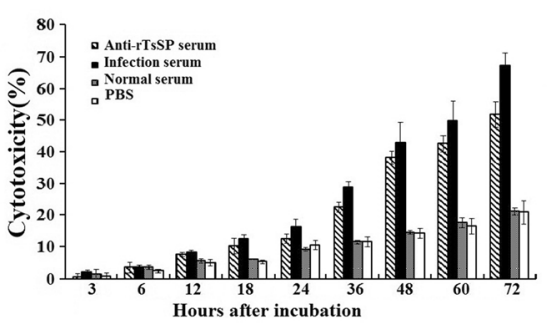

$\mathbf{E}$

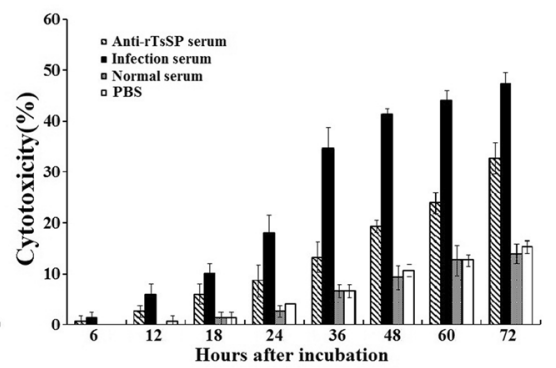

C

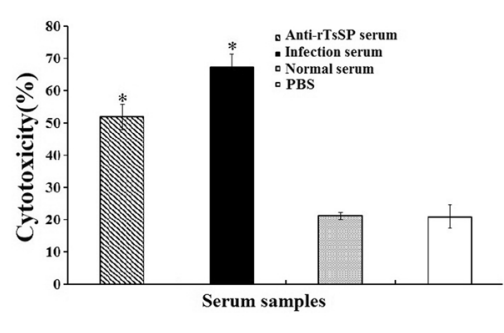

F

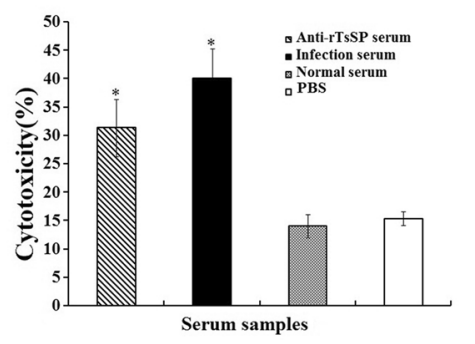

Figure 12 ADCC assays of T. spiralis NBL (A-C) and ML (D-F). A, D The cytotoxicity was anti-rTsSP antibody dose-dependent. B, E The cytotoxicity had an increasing trend with prolonged culture time. C, F ADCC assay with different serum. When 1:100 dilutions of different serum was used and cultured for $72 \mathrm{~h}$, the ADCC with anti-rTsSP serum caused the evident death of NBL $(\mathbf{C})$ and ML (F), compared with the larvae incubated by normal mouse serum (pre-immune serum). Asterisks show a statistically prominent difference $(P<0.01)$ in comparison with normal serum. 

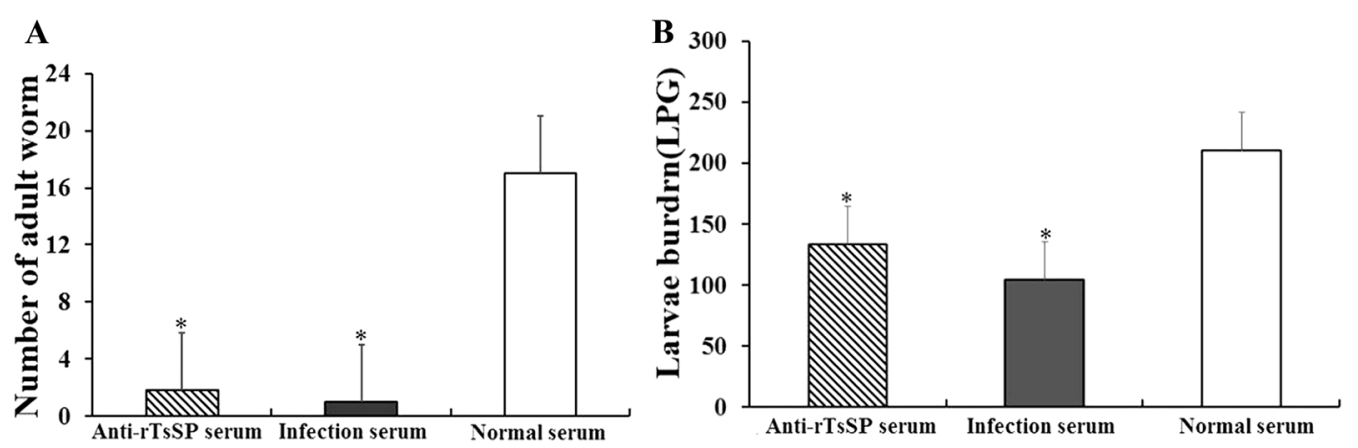

Figure 13 Identification of the infectivity of $\boldsymbol{T}$. spiralis ML treated by ADCC assay. Worm burden of intestinal adults (A) and muscle larvae (B) was assessed in mice inoculated orally with T. spiralis ML treated by ADCC assay. The ML were incubated with 1:100 dilutions of anti-rTsSP serum and $2 \times 10^{5}$ mouse peritoneal macrophages (PM) at $37^{\circ} \mathrm{C}$ for $24 \mathrm{~h}$. Three groups of mice were orally inoculated with $100 \mathrm{ML}$ treated by ADCC assay. The results are shown as the mean $\pm \mathrm{SD}(n=6)$. Asterisks demonstrate a remarkable difference $(P<0.01)$ in parasite burdens of the anti-rTsSP serum group relative to those in the normal serum group.
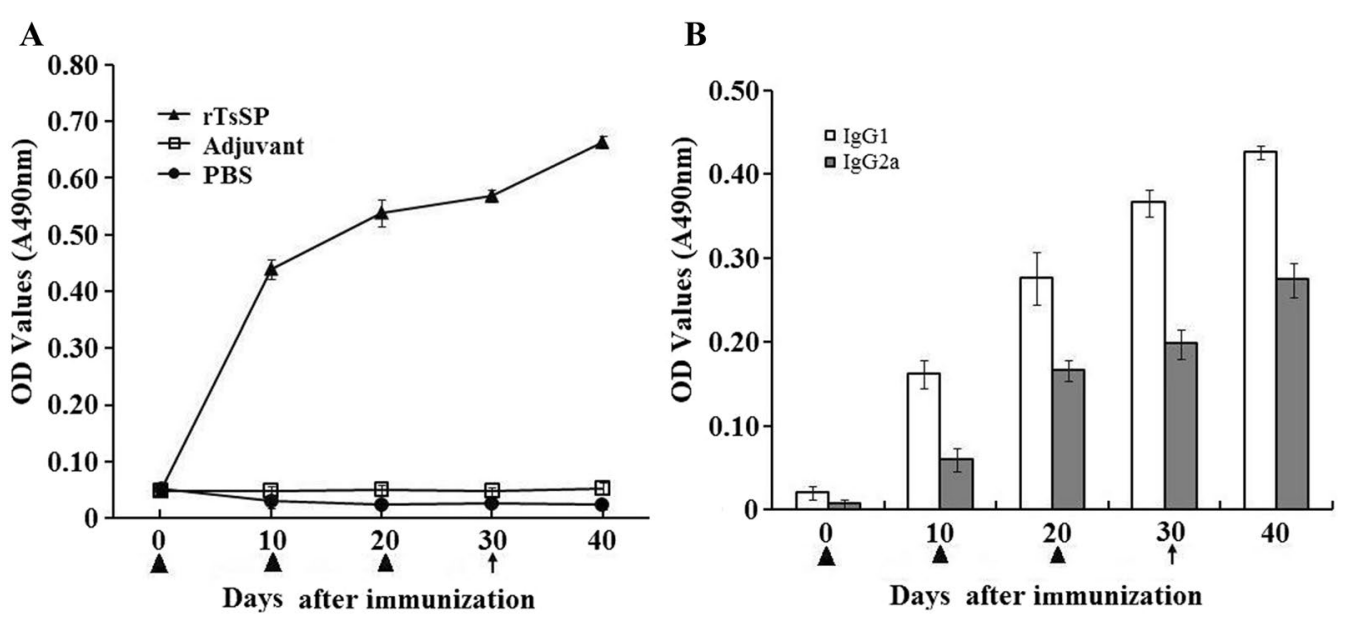

Figure 14 Analysis of anti-rTsSP IgG responses in mice vaccinated with rTsSP. A Anti-rTsSP IgG levels in sera of immunized mice at diverse time intervals after immunization. B The lgG subclass response of immunized mice was observed at diverse time intervals after immunization. The $\mathrm{OD}$ values of each group are the mean \pm SD of 10 mice. The vaccination times are marked as a triangle, and challenge infection time is marked as an arrow.

impeded larval development in the host by an ADCC mechanism [30]. These results further revealed that TsSP could be an essential protease for invasion, development and survival of this nematode.

Th2-predominant immune responses were successfully induced by vaccination of mice with rTsSP. After being orally infected by $T$. spiralis $\mathrm{ML}$, the mice immunized with rTsSP displayed a 52.70\% reduction of intestinal adult worm burden at $5 \mathrm{dpi}$ and a $52.10 \%$ muscle larval reduction at $42 \mathrm{dpi}$. The worm burden reduction is similar with those of previous studies [26, 32, 38, 45]. The results demonstrate that the immunization of mice with an individual recombinant Trichinella protein could only elicit a partial immune protection against challenge infection. Besides, the immune protection of TsSP should be investigated in a domestic pig animal model. In addition, polyvalent oral vaccines against enteral invasive stages of $T$. spiralis need to be developed in further studies $[11,64,65]$.

In summary, our results reveal that TsSP is expressed at diverse $T$. spiralis phases. The rTsSP can specifically bind to and interact with host's IEC. Anti-rTsSP antibodies inhibited the larval invasion of the host's enterocyte in a dose-dependent manner. Anti-rTsSP antibodies also killed the T. spiralis NBL and ML, decreased larval infectivity and development in the 

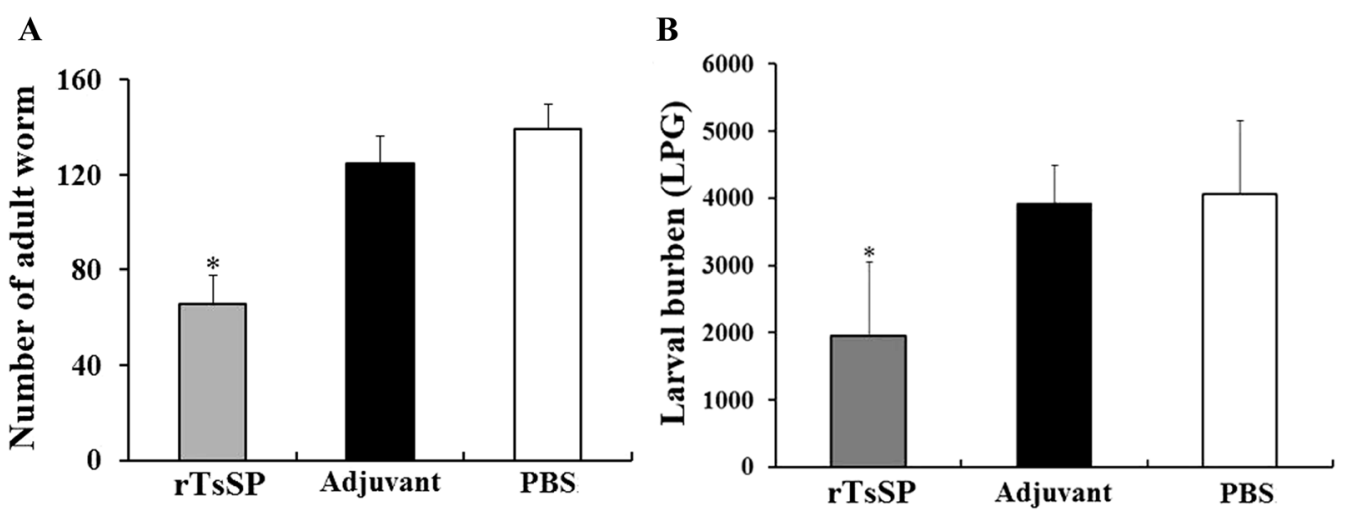

Figure 15 Worm burdens of intestinal adults (A) and muscle larvae (B) recovered from three groups of mice after being infected with 300 muscle larvae of $\boldsymbol{T}$. spiralis. Results are expressed as the mean \pm SD of 10 mice per group. Asterisks demonstrate an obvious difference $(P<0.01)$ in terms of worm burdens from rTsSP-immunized mice in comparison with the adjuvant and PBS groups.

host by an ADCC mode. The vaccination of mice with rTsSP produced Th2 predominant immune response and a partial immune protection against challenge infection. The results suggest that TsSP might be an indispensable protease for invasion and development of this nematode. It is likely a potential vaccine target against enteral Trichinella infection. But, polyvalent oral vaccines against enteral $T$. spiralis stages need to be further developed.

\section{Abbreviations}

ADCC: antibody-dependent cellular cytotoxicity; AW: adult worms; BSA: bovine serum albumin; DAPI: 4',6-diamidino-2-phenylindole; dpi: days post-infection; ES: excretory-secretory; FCA: Freund's complete adjuvant; FIA: Freund's incomplete adjuvant; G3PDH: glyceraldehyde 3-phosphate dehydrogenase; hpi: hour post-infection; ICT: International Commission on TrichinelIosis; IEC: intestinal epithelial cell; IFT: immunofluorescent test; IIL: intestinal infective larvae; IPTG: isopropyl $\beta$-D-1-thiogalactopyranoside; LPG: larvae per gram; ML: muscle larvae; MPM: mouse peritoneal macrophages; NBL: newborn larvae; OPD: o-phenylenediamine dihydrochloride; ORF: open reading frame; PI: propidium iodide; qPCR: quantitative PCR; TBS: tris-buffered saline; TsSP: Trichinella spiralis putative serine protease.

\section{Competing interests}

The authors declare that they have no competing interests.

\section{Authors' contributions}

ZQW and JC conceived and designed this study. GGS, HNR, RDL, YYS, XQ, $\mathrm{CXH}, \mathrm{FY}, \mathrm{PJ}$, and XZ performed the experiments. GGS analyzed the data with assistance of PJ and RDL. GGS, ZQW and JC drafted the manuscript. All authors read and approved the final manuscript.

\section{Acknowledgements}

This study was supported by Grants of the National Natural Science Foundation of China (Nos. 81471981, U1704284 and 81672043).

\section{Ethics approval and consent to participate}

This study was conducted in accordance with the National Guidelines for Experimental Animal Welfare, Ministry of Science and Technology of the People's Republic of China, 2006. All animal care and use in this experiment were approved by the Life Science Ethics Committee of Zhengzhou University (No. SCXK 2015-0005).

\section{Publisher's Note}

Springer Nature remains neutral with regard to jurisdictional claims in published maps and institutional affiliations.

Received: 27 February 2018 Accepted: 8 May 2018

Published online: 13 July 2018

\section{References}

1. Bruschi F (2012) Trichinellosis in developing countries: is it neglected? J Infect Dev Ctries 6:216-222

2. Cui J, Wang ZQ (2011) An epidemiological overview of swine trichinellosis in China. Vet J 190:323-328

3. Pozio E (2007) World distribution of Trichinella spp. infections in animals and humans. Vet Parasitol 149:3-21

4. Murrell KD, Pozio E (2011) Worldwide occurrence and impact of human trichinellosis 1986-2009. Emerg Infect Dis 17:2194-2202

5. Cui J, Wang ZQ, Xu BL (2011) The epidemiology of human trichinellosis in China during 2004-2009. Acta Trop 118:1-5

6. Cui J, Jiang P, Liu LN, Wang ZQ (2013) Survey of Trichinella infections in domestic pigs from northern and eastern Henan, China. Vet Parasitol 194:133-135

7. Jiang P, Zhang X, Wang LA, Han LH, Yang M, Duan JY, Sun GG, Qi X, Liu RD, Wang ZQ, Cui J (2016) Survey of Trichinella infection from domestic pigs in the historical endemic areas of Henan province, central China. Parasitol Res 115:4707-4709

8. Rostami A, Gamble HR, Dupouy-Camet J, Khazan H, Bruschi F (2017) Meat sources of infection for outbreaks of human trichinellosis. Food Microbiol 64:65-71

9. Bai X, Hu XX, Liu XL, Tang B, Liu MY (2017) Current research of trichinellosis in China. Front Microbiol 8:1472

10. Liu P, Wang ZQ, Liu RD, Jiang P, Long SR, Liu LN, Zhang XZ, Cheng XC, Yu C, Ren HJ, Cui J (2015) Oral vaccination of mice with Trichinella spiralis nudix hydrolase DNA vaccine delivered by attenuated Salmonella elicited protective immunity. Exp Parasitol 153:29-38

11. GuY, Sun XM, Li B, Huang JJ, Zhan B, Zhu X (2017) Vaccination with a paramyosin-based multi-epitope vaccine elicits significant protective immunity against Trichinella spiralis infection in mice. Front Microbiol 8:1475

12. Wang L, Sun XM, Huang JJ, Zhan B, Zhu XP (2017) Heterologous primeboost vaccination enhances TsPmy's protective immunity against Trichinella spiralis infection in a murine model. Front Microbiol 8:1394

13. XU J, Bai X, Wang LB, Shi HN, Giessen JWB, Boireau P, Liu MY, Liu XL (2017) Immune responses in mice vaccinated with a DNA vaccine expressing serine protease-like protein from the new-born larval stage of Trichinella spiralis. Parasitology 144:712-719 
14. Wang L, Wang ZQ, Cui J (2013) Protein changes in Trichinella spiralis muscle larvae in vitro induced by bovine bile. Vet Parasitol 194:164-167

15. Gagliardo LF, McVay CS, Appleton JA (2002) Molting, ecdysis, and reproduction of Trichinella spiralis are supported in vitro by intestinal epithelial cells. Infect Immun 70:1853-1859

16. Campbell WC (1983) Trichinella and trichinosis. Plenum Press, New York, pp 75-151

17. Wang L, Cui J, Hu DD, Liu RD, Wang ZQ (2014) Identification of early diagnostic antigens from major excretory-secretory proteins of Trichinella spiralis muscle larvae using immunoproteomics. Parasit Vectors 7:40

18. Liu RD, Cui J, Liu XL, Jiang P, Sun GG, Zhang X, Long SR, Wang L, Wang ZQ (2015) Comparative proteomic analysis of surface proteins of Trichinella spiralis muscle larvae and intestinal infective larvae. Acta Trop 150:79-86

19. Liu RD, Jiang P, Wen H, Duan JY, Wang LA, Li JF, Liu CY, Sun GG, Wang ZQ, Cui J (2016) Screening and characterization of early diagnostic antigens in excretory-secretory proteins from Trichinella spiralis intestinal infective larvae by immunoproteomics. Parasitol Res 115:615-622

20. Wang ZQ, Wang L, Cui J (2012) Proteomic analysis of Trichinella spiralis proteins in intestinal epithelial cells after culture with their larvae by shotgun LC-MS/MS approach. J Proteomics 75:2375-2383

21. Wang L, Wang ZQ, Cui J (2013) Proteomic analysis of the changed proteins of Trichinella spiralis infective larvae after co-culture in vitro with intestinal epithelial cells. Vet Parasitol 194:160-163

22. Wang ZQ, Liu RD, Sun GG, Song YY, Jiang P, Zhang X, Cui J (2017) Proteomic analysis of Trichinella spiralis adult worm excretory-secretory proteins recognized by sera of patients with early Trichinellosis. Front Microbiol 8:986

23. Gamble HR, Bessonov AS, Cuperlovic K, Gajadhar AA, van Knapen F, Noeckler K, Schenone H, Zhu X (2000) International Commission on Trichinellosis: recommendations on methods for the control of Trichinella in domestic and wild animals intended for human consumption. Vet Parasitol 93:393-408

24. Li F, Cui J, Wang ZQ, Jiang P (2010) Sensitivity and optimization of artificial digestion in the inspection of meat for Trichinella spiralis. Foodborne Pathog Dis 7:879-885

25. Wu ZL, Nagano I, Takahashi Y, Maekawa Y (2016) Practical methods for collecting Trichinella parasites and their excretory-secretory products. Parasitol Int 65:591-595

26. Wang B, Wang ZQ, Jin J, Ren HJ, Liu LN, Cui J (2013) Cloning, expression and characterization of a Trichinella spiralis serine protease gene encoding a 35.5 kDa protein. Exp Parasitol 134:148-154

27. Bradford MM (1976) A rapid and sensitive method for the quantitation of microgram quantities of protein utilizing the principle of protein-dye binding. Anal Biochem 72:248-254

28. Ren HJ, Cui J, Wang ZQ, Liu RD (2011) Normal mouse intestinal epithelial cells as a model for the in vitro invasion of Trichinella spiralis infective larvae. PLoS One 6:e27010

29. ManWarren TGL, Geyer J, McVay C, Pearce-Kelling S, Appleton J (1997) Invasion of intestinal epithelia in vitro by the parasitic nematode Trichinella spiralis. Infect Immun 65:4806-4812

30. Long SR, Wang ZQ, Jiang P, Liu RD, Qi X, Liu P, Ren HJ, Shi HN, Cui J (2015) Characterization and functional analysis of Trichinella spiralis nudix hydrolase. Exp Parasitol 159:264-273

31. Sun GG, Song YY, Jiang P, Ren HN, Yan SW, Han Y, Liu RD, Zhang X, Wang ZQ, Cui J (2018) Characterization of a Trichinella spiralis putative serine protease. Study of its potential as sero-diagnostic tool. PLoS Negl Trop Dis 12:e0006485

32. Cui J, Ren HJ, Liu RD, Wang L, Zhang ZF, Wang ZQ (2013) Phage-displayed specific polypeptide antigens induce significant protective immunity against Trichinella spiralis infection in BALB/c mice. Vaccine 31:1171-1177

33. Cui J, Wang L, Sun GG, Liu LN, Zhang SB, Liu RD, Zhang X, Jiang P, Wang ZQ (2015) Characterization of a Trichinella spiralis $31 \mathrm{kDa}$ protein and its potential application for the serodiagnosis of trichinellosis. Acta Trop 142:57-63

34. Liu RD, Wang ZQ, Wang L, Long SR, Ren HJ, Cui J (2013) Analysis of differentially expressed genes of Trichinella spiralis larvae activated by bile and cultured with intestinal epithelial cells using real-time PCR. Parasitol Res 112:4113-4120

35. Liu CY, Song YY, Ren HN, Sun GG, Liu RD, Jiang P, Long SR, Zhang X, Wang ZQ, Cui J (2017) Cloning and expression of a Trichinella spiralis putative glutathione S-transferase and its elicited protective immunity against challenge infections. Parasit Vectors 10:448

36. Yang YR, Jian W, Qin WW, Tian GM (2013) Characterization of TsMRP-L28, a mitochondrial ribosomal protein $\mathrm{L} 28$ from the parasitic nematode Trichinella spiralis. Gene 512:496-504

37. Liao CS, Liu MY, Bai X, Liu P, Wang XL, Li T, Tang B, Gao H, Sun Q, Liu X, Zhao Y, Wang F, Wu X, Boireau P, Liu X (2014) Characterisation of a Plancitoxin-1-Like DNase II gene in Trichinella spiralis. Plos Neglect Trop Dis 8:e3097

38. Long SR, Wang ZQ, Liu RD, Liu LN, Li LG, Jiang P, Zhang X, Zhang ZF, Shi HN, Cui J (2014) Molecular identification of Trichinella spiralis nudix hydrolase and its induced protective immunity against trichinellosis in BALB/C mice. Parasit Vectors 7:600

39. Liu P, Cui J, Liu RD, Wang M, Jiang P, Liu LN, Long SR, Li LG, Zhang SB, Zhang XZ, Wang ZQ (2015) Protective immunity against Trichinella spiralis infection induced by TsNd vaccine in mice. Parasit Vectors 8:185

40. Wang SW, Wang ZQ, Cui J (2011) Protein change of intestinal epithelial cells induced in vitro by Trichinella spiralis infective larvae. Parasitol Res 108:593-599

41. Sun GG, Liu RD, Wang ZQ, Jiang P, Wang L, Liu XL, Liu CY, Zhang X, Cui $J$ (2015) New diagnostic antigens for early trichinellosis: the excretorysecretory antigens of Trichinella spiralis intestinal infective larvae. Parasitol Res 114:4637-4644

42. Cui J, Li LG, Jiang P, Liu RD, Yang X, Liu LN, Liu P, Zhang SB, Wang ZQ (2015) Biochemical and functional characterization of the glutathione S-transferase from Trichinella spiralis. Parasitol Res 114:2007-2013

43. Moskwa B (1999) Trichinella spiralis: in vitro cytotoxicity of peritoneal cells against synchronous newborn larvae of different age. Parasitol Res 85:59-63

44. Liu LN, Wang ZQ, Zhang X, Jiang P, Qi X, Liu RD, Zhang ZF, Cui J (2015) Characterization of Spirometra erinaceieuropaei plerocercoid cysteine protease and potential application for serodiagnosis of sparganosis. PLoS Negl Trop Dis 9:e0003807

45. Li LGWZ, Liu RD, Yang X, Liu LN, Sun GG, Jiang P, Zhang X, Zhang GY, Cui J (2015) Trichinella spiralis: low vaccine potential of glutathione S-transferase against infections in mice. Acta Trop 146:25-32

46. Hedstrom $L$ (2002) Serine protease mechanism and specificity. Chem Rev 102:4501-4524

47. Nagano I, Wu Z, Nakada T, Boonmars T, Takahashi Y (2003) Molecular cloning and characterization of a serine proteinase gene of Trichinella spiralis. J Parasitol 89:92-98

48. Yang Y, Wen Y, Cai YN, Vallee I, Boireau P, Liu MY, Cheng SP (2015) Serine proteases of parasitic helminths. Korean J Parasitol 53:1-11

49. Dalton JP, Clough KA, Jones MK, Brindley PJ (1997) The cysteine proteinases of Schistosoma mansoni cercariae. Parasitology 114:105-112

50. Haffner A, Guilavogui AZ, Tischendorf FW, Brattig NW (1998) Onchocerca volvulus: microfilariae secrete elastinolytic and males nonelastinolytic matrix-degrading serine and metalloproteases. Exp Parasitol 90:26-33

51. Hotez PJ, Cerami A (1983) Secretion of a proteolytic anticoagulant by Ancylostoma hookworms. J Exp Med 157:1594-1603

52. Hasnain SZ, McGuckin MA, Grencis RK, Thornton DJ (2012) Serine protease(s) secreted by the nematode Trichuris muris degrade the mucus barrier. PLoS Negl Trop Dis 6:e1856

53. Romaris F, North SJ, Gagliardo LF, Butcher BA, Ghosh K, Beiting DP, Panico M, Arasu P, Dell A, Morris HR, Appleton JA (2002) A putative serine protease among the excretory-secretory glycoproteins of L1 Trichinella spiralis. Mol Biochem Parasit 122:149-160

54. Robinson MW, Connolly B (2005) Proteomic analysis of the excretorysecretory proteins of the Trichinella spiralis L1 larva, a nematode parasite of skeletal muscle. Proteomics 5:4525-4532

55. Criado-Fornelio A, de Armas-Serra C, Gimenez-Pardo C, Casado-Escribano N, Jimenez-Gonzalez A, Rodríguez-Caabeiro F (1992) Proteolytic enzymes from Trichinella spiralis larvae. Vet Parasitol 45:133-140

56. Todorova VK, Knox DP, Kennedy MW (1995) Proteinases in the excretory/secretory products (ES) of adult Trichinella spiralis. Parasitology 111:201-208

57. Ren HJ, Cui J, Yang W, Liu RD, Wang ZQ (2013) Identification of differentially expressed genes of Trichinella spiralis larvae after exposure to host intestine milieu. PLoS One 8:e67570

58. Feng S, Wu XP, Wang XL, Bai X, Shi HN, Tang B, Liu X, Song Y, Boireau P, Wang F, Zhao Y, Liu M (2013) Vaccination of mice with an antigenic serine 
protease-like protein elicits a protective immune response against Trichinella spiralis infection. J Parasitol 99:426-432

59. Yang Y, Lacour SA, Laine-Prade V, Versille N, Grasset-Chevillot A, Feng S, Liu MY, Boireau P, Vallée I (2015) Trichinella spiralis newborn larvae: characterization of a stage specific serine proteinase expression, NBL1, using monoclonal antibodies. Parasitology 142:783-790

60. Bien J, Cabaj W, Moskwa B (2015) Proteomic analysis of potential immunoreactive proteins from muscle larvae and adult worms of Trichinella spiralis in experimentally infected pigs. Folia Parasitol 62(2015):022

61. Sato YKM, Arai H, Ishii M, Igarashi Y (2011) Detecting weak proteinprotein interactions by modified far-western blotting. J Biosci Bioeng 112:304-307

62. Butcher BA, Gagliardo LF, ManWarren T, Appleton JA (2000) Larvaeinduced plasma membrane wounds and glycoprotein deposition are insufficient for Trichinella spiralis invasion of epithelial cells. Mol Biochem Parasitol 107:207-218

63. McVay CS, Tsung A, Appleton J (1998) Participation of parasite surface glycoproteins in antibody-mediated protection of epithelial cells against Trichinella spiralis. Infect Immun 66:1941-1945

64. Pompa-Mera EN, Arroyo-Matus P, Ocana-Mondragon A, Gonzalez-Bonilla $C R$, Yepez-Mulia L (2014) Protective immunity against enteral stages of Trichinella spiralis elicited in mice by live attenuated Salmonella vaccine that secretes a 30-mer parasite epitope fused to the molecular adjuvant C3d-P28. Res Vet Sci 97:533-545

65. Liu JY, Zhang NZ, Li WH, Li L, Yan HB, Qu ZG, Li TT, Cui JM, Yang Y, Jia WZ, Fu BQ (2016) Proteomic analysis of differentially expressed proteins in the three developmental stages of Trichinella spiralis. Vet Parasitol 231:32-38
Ready to submit your research? Choose BMC and benefit from:

- fast, convenient online submission

- thorough peer review by experienced researchers in your field

- rapid publication on acceptance

- support for research data, including large and complex data types

- gold Open Access which fosters wider collaboration and increased citations

- maximum visibility for your research: over $100 \mathrm{M}$ website views per year

At BMC, research is always in progress.

Learn more biomedcentral.com/submissions 